\title{
EUROCAT: an update on its functions and activities
}

\author{
F. D. Tucker ${ }^{1}$ - J. K. Morris ${ }^{2}$ on behalf of the JRC Management Committee $\cdot$ A. Neville ${ }^{3} \cdot$ E. Garne $^{4}$.

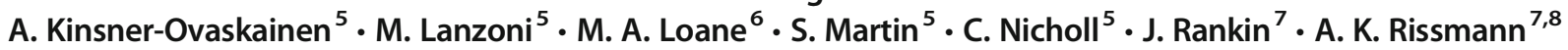

Received: 8 September 2017 / Accepted: 19 April 2018 / Published online: 7 May 2018

(C) Springer-Verlag GmbH Germany, part of Springer Nature 2018

\begin{abstract} transferred from the Ulster University to the EU Joint-Research-Centre, Ispra, Italy. these data can be put. These uses include:

. surveillance of anomalies at a local, regional or pan-European level

. pharmacovigilance

. registration of rare diseases
\end{abstract}

This paper provides an outline of the development and growth of EUROCAT, the European network of congenital anomaly registers. In recent years the network has been through a period of transition and change. The Central Register of data has

The benefits of combining data from across Europe, from different populations and countries are described by the uses to which

New studies and projects are underway, including EUROlinkCAT (a Horizon 2020 funded data-linkage project), promising a fruitful future in further research of congenital anomalies.

EUROCAT, founded in 1979 as the European Concerted Action on Congenital Anomalies and Twins, is a high quality network of population based congenital anomaly registries

F. D. Tucker

david.tucker2@wales.nhs.uk

1 Congenital Anomaly Register \& Information Service for Wales (CARIS) Public Health Wales, Swansea, UK

2 Centre for Environmental and Preventive Medicine, Wolfson Institute of Preventive Medicine, Barts and the London School of Medicine and Dentistry, Queen Mary University of London, London, UK

3 IMER Registry (Emilia Romagna Registry of Birth Defects), University of Ferrara and Azienda Ospedaliero Universitaria di Ferrara, Ferrara, Italy

4 Paediatric Department, Hospital Lillebaelt, Kolding, Denmark

5 DG Joint Research Centre, Directorate F - Health Consumers and Reference Materials, Ispra, Italy

6 Institute of Nursing and Health Research, Ulster University, Newtownabbey, UK

7 Institute of Health and Society, Newcastle University, Newcastle, UK

8 Malformation Monitoring Centre Saxony-Anhalt, Medical Faculty, Otto-von-Guericke University Magdeburg, Magdeburg, Germany across Europe for the monitoring, surveillance and research of congenital anomalies (Boyd et al. 2011a). Since its conception the European Commission (EC) has funded the EUROCAT Central Registry.

The EUROCAT Central Registry was based in Brussels from 1979 to 1999 and then moved to the UK. From 2000 to 2014, it was accommodated at the University of Ulster, led superbly by Professor Helen Dolk. In January 2015, the Central Registry transferred to the European Commission's Joint Research Centre (DG JRC) in Ispra, Italy. EUROCAT is now an integral part of the European Platform on Rare Diseases Registration being developed at the JRC (Martin et al. 2016) in close collaboration with the EC's Directorate for Health and Food safety (DG SANTE).

Over the last two decades EUROCAT has grown, developed and matured in many directions to be the successful network that is recognised around the world today. (Other research groups now apply our methodology and use our publications as reference.) Greater standardisation of definitions, diagnoses and terminology were achieved, principally by the development of the EUROCAT guides (currently version 1.4) (EUROCAT 2016), the EUROCAT Central Database and the EUROCAT Data Management Program (ECD and EDMP) (EUROCAT 2013) which constrained registers to adopt 
common practices in data reporting. The EUROCAT Coding and Classification Committee from 2003 onwards also played its role, by defining cases, developing and disseminating rules around classification and coding and providing support and training in applying these rules.

Currently, the EUROCAT Central Registry holds details on approximately 750,000 cases of congenital anomalies collected over the years by 51 registries, contributing either anonymous individual case specific data (full members) or aggregate prevalence data in tables (associate members), from 23 countries covering almost $30 \%$ of European births (1.7 million) per year.

The great value of EUROCAT is that the data are collected, coded and stored by local registries in a standardised way. This inherent homogeneity in the data across Europe (Boyd et al. 2011b) overcomes the weaknesses of many studies which attempt to derive information from heterogeneous datasets.

One key function of EUROCAT is to publish statistics on outcomes and prevalence rates for a wide range of major congenital anomalies annually. The data covers all pregnancy outcomes (including terminations) from 20 weeks gestation. Much of this information is freely available on the EUROCAT website (http://www.eurocat-network.eu/ accessprevalancedata/prevalencetables - last accessed $24^{\text {th }}$ August 2017). Having good quality baseline background data is vital when considering possible environmental impacts (EUROCAT 2013). A recent publication highlighted the differences in the diagnosis of microcephaly across Europe, a matter of importance when interpreting the prevalence of microcephaly across South America with the emergence of Zika virus (Morris et al. 2016). The value of robust baseline data has also been demonstrated by work undertaken in Italy (Pirastu et al. 2010), investigating environmental exposures.

EDMP has a built-in module for calculating trends and clusters, designed as an "early response" system (Teljeur et al. 2015; Dolk et al. 2015). This can be used by individual registers to review their own data or by the Central Registry combining data. It is interesting to see that what can often appear to be a local or national trend to an individual register or group of registers within one country can in fact be part of something wider and larger across the whole of Europe. Trends may increase because of better diagnosis (improvements in antenatal ultrasound scanning for example) or because of environmental factors that are not well understood (Loane et al. 2011). For instance, there is marked variation in the prevalence of gastroschisis in some northern European countries compared to the Mediterranean region (Loane et al. 2007). On the other hand, the increasing use of ultrasound scans pre and postnatally has made it more difficult to determine and harmonise the exact limit between normal and abnormal findings in foetuses and newborn babies (Garne et al. 2009).
However, perhaps the greatest value of combining data can be seen for rare diseases. No individual registry will ever have enough cases to accurately determine prevalence for rare and very rare conditions. By combining data this can be achieved. Over recent years, EUROCAT papers have been published on Holt-Oram syndrome (Barisic et al. 2014a), Meckle-Gruber syndrome (Barisic et al. 2015), Ocular-Auricular-Vertebral syndrome (Barisic et al. 2014b) and Fraser syndrome (Barisic et al. 2013). The value of combining data can be seen even in common conditions such as trisomy 21 , where factors such as twinning (Boyle et al. 2014) require Europe-wide data in order to be explored effectively. EUROCAT representatives are also involved with some of the recently established European Reference Networks (ERNS) (https://ec.europa.eu/health/ern/ policy_en - last accessed 16th August 2017) for rare diseases.

Another area of interest is the impact of health service policies and practice. Improvements in antenatal detections of anomalies and increasing survival for live born infants seen with cardiac anomalies demonstrate this (Dolk et al. 2011). Other work includes the development of indicators to summarise the public health impact of congenital anomalies, including mortality. Survival to 1 week and 1 year varies enormously between countries mainly because of different legislation regarding termination. Death at 1 week is much higher in those countries where terminations are not legal (Malta and Ireland) compared to other countries (Khoshnood et al. 2011; Boyle et al. 2017).

The lack of fortification of foodstuffs with folic acid in European countries has been a matter of deep regret to EUROCAT. Whilst the USA (Mathews and National Center for Health Statistics 2007), Canada (De Wals et al. 2007) and other places (López-Camelo et al. 2005; Sayed et al. 2008) have been able to demonstrate a significant fall in the rates of neural tube defects due to fortification, EUROCAT consistently reports that neural defects rates across Europe remain stubbornly stable. Sadly this demonstrates usefulness in highlighting a failure of Public Health action in the European member states (Busby et al. 2005; Neville and de Walle 2010; Khoshnood et al. 2015).

EUROCAT continues to develop methods to improve the surveillance of congenital anomalies. One example is the development of a coding algorithm, which has been implemented in EDMP to allow for classification of multiple congenital anomalies where there is no unifying diagnosis of a syndrome or chromosomal anomaly for separate surveillance. Patterns of occurrence are looked for, which may suggest possible pathways for teratogens, or other aetiological causation (Garne et al. 2011).

Pharmocovigilance has been an area of study of increasing importance over the last 10 years (EUROCAT 2014; Charlton et al. 2014). EUROCAT has demonstrated the value of such work, particularly through the EUROmediCAT project (http:// euromedicat.eu/ - last accessed $15^{\text {th }}$ August 2017) in which 
medications taken during the first trimester of pregnancy, for certain long-term or chronic diseases have been assessed. The medications studied include anti-epileptics, SSRIs, anti-asthmatics, and diabetic medicines. The EUROmediCAT project involved a data-linkage approach between registers and national prescription databases.

Recently a new data-linkage project has been launchedEUROlinkCAT (https://www.eurolinkcat.eu/ - last accessed $15^{\text {th }}$ August 2017) funded by the Horizon 2020 project. By linking data between registers and other national databases, it is hoped that a far more detailed and extensive picture can be described on the long-term consequence for infants born with major congenital anomalies, consequences in terms of survival, morbidity, health service usage and demands, and educational achievement.

These linkage projects highlight a widespread change in registration practice in recent years, with less reliance upon paper reports and linkage to health databases and systems becoming routine at the local level.

Collaborative studies are often developed by thematic Working Groups that are constituted whenever new research needs arise. Two recently established groups are Genetics, and Health Inequalities. In this way, EUROCAT remains relevant and flexible to adapt to changes in the clinical world.

EUROCAT is an invaluable resource. With so many opportunities for further studies, and for pushing forward the scientific understanding of congenital anomalies, a bright future for EUROCAT beckons. We are confident that being part of the European Platform on Rare Disease Registration will give the stability and support to build upon EUROCAT's past successes and to achieve even greater things in the years ahead.

\section{Compliance with ethical standards}

This article does not contain any studies with human or animal subjects performed by the any of the authors.

Conflict of interest The authors declare that they have no conflict of interest.

\section{References}

Barisic I, Odak L, Loane M, Garne E, Wellesley D, Calzolari E, Dolk H, Addor MC, Arriola L, Bergman J, Bianca S (2013) Fraser syndrome: epidemiological study in a European population. Am J Med Genet A 161(5):1012-1018

Barisic I, Boban L, Greenlees R, Garne E, Wellesley D, Calzolari E, Addor MC, Arriola L, Bergman JE, Braz P, Budd JL (2014a) Holt Oram syndrome: a registry-based study in Europe. Orphanet J Rare Dis 9(1):156

Barisic I, Odak L, Loane M, Garne E, Wellesley D, Calzolari E, Dolk H, Addor MC, Arriola L, Bergman J, Bianca S (2014b) Prevalence, prenatal diagnosis and clinical features of oculo-auriculo-vertebral spectrum: a registry-based study in Europe. Eur J Hum Genet 22(8): 1026

Barisic I, Boban L, Loane M, Garne E, Wellesley D, Calzolari E, Dolk H, Addor MC, Bergman JE, Braz P, Draper ES (2015) Meckel-Gruber Syndrome: a population-based study on prevalence, prenatal diagnosis, clinical features, and survival in Europe. Eur J Hum Genet 23(6):746

Boyd P, Barisic I, Haeusler M, Loane M, Garne E, Dolk H (2011a) Paper 1: The EUROCAT network: organization and processes. Birth Defects Res A 91:2-15 [full text]

Boyd P, Haeusler M, Barisic I (2011b) EUROCAT report 9: surveillance of congenital anomalies in Europe 1980-2008. Birth Defects Res A 91:S1 [full text]

Boyle B, Morris JK, McConkey R, Garne E, Loane M, Addor MC, Gatt M, Haeusler M, Latos-Bielenska A, Lelong N, McDonnell R (2014) Prevalence and risk of Down syndrome in monozygotic and dizygotic multiple pregnancies in Europe: implications for prenatal screening. BJOG Int J Obstet Gynaecol 121(7):809-820

Boyle B, Addor MC, Arriola L, Barisic I, Bianchi F, Csáky-Szunyogh M, de Walle HE, Dias CM, Draper E, Gatt M and Garne E (2017) Estimating global burden of disease due to congenital anomaly: an analysis of European data. Arch Dis Child Fetal Neonatal Ed, pp.fetalneonatal-2016

Busby A, Armstrong B, Dolk H, Armstrong N, Haeusler M, Berghold A, Gillerot Y, Baguette A, Gjergja R, Barisic I, Christiansen M (2005) Preventing neural tube defects in Europe: a missed opportunity. Reprod Toxicol 20(3):393-402

Charlton R, Neville A, Jordan S, Pierini A, Damase-Michel C, Klungsoyr K, Nybo Andersen A-M, Vinkel Hansen A, Gini R, Bos HJ, Puccini A, Hurault-Delarue C, Brooks C, de Jong-van den Berg L, de Vries C (2014) Healthcare databases in Europe for studying medicine use and safety during pregnancy. Pharmacoepidemiol Drug Saf [Full Text ] 23:586-594

De Wals P, Tairou F, Van Allen MI, Uh SH, Lowry RB, Sibbald B, Evans JA, Van den Hof MC, Zimmer P, Crowley M, Fernandez B (2007) Reduction in neural-tube defects after folic acid fortification in Canada. N Engl J Med 357(2):135-142

Dolk H, Loane M, Garne E, European Surveillance of Congenital Anomalies (EUROCAT) Working Group (2011) Congenital heart defects in Europe. Circulation 123(8):841-849

Dolk H, Loane M, Teljeur C, Densem J, Greenlees R, McCullough N, Morris J, Nelen V, Bianchi F, Kelly A (2015) Detection and investigation of temporal clusters of congenital anomaly in Europe: seven years of experience of the EUROCAT surveillance system. Eur J Epidemiol 30(11):1153-1164

EUROCAT (2013) EDMP user guide. Retrieved August 15, 2017, from EUROCAT: http://www.eurocat-network.eu/aboutus/ datacollection/edmp/edmpuserguide

EUROCAT (2013) EUROCAT special report: actions towards European environmental surveillance: feasibility of environmental linkage. EUROCAT Central Registry, University of Ulster. [full text]

EUROCAT (2014) EUROCAT special report: sources of information of medication use in pregnancy. EUROCAT Central Registry, University of Ulster. [full text

EUROCAT (2016) EUROCAT guide 1.4. Retrieved August 15, 2017, from EUROCAT: www.eurocat-network.eu/aboutus/datacollection/ guidelinesforregistration/guide1_4

Garne E, Loane M, Wellesley D, Barisic I, Eurocat Working Group (2009) Congenital hydronephrosis: prenatal diagnosis and epidemiology in Europe. J Pediatr Urol 5(1):47-52

Garne E, Dolk H, Loane M, Wellesley D, Barisic I, Calzolari E, Densem J (2011) Paper 5: surveillance of multiple congenital anomalies: implementation of a computer algorithm in European registers for classification of cases. Birth Defects Res A 91(S1):S44-S50 
Khoshnood B, Greenlees R, Loane M, Dolk H (2011) Paper 2: EUROCAT public health indicators for congenital anomalies in Europe. Birth Defects Res A 91(S1):S16-S22

Khoshnood B, Loane M, De Walle H, Arriola L, Addor MC, Barisic I, Beres J, Bianchi F, Dias C, Draper E, Garne E (2015) Long term trends in prevalence of neural tube defects in Europe: population based study. Bmj 351:h5949

Loane M, Dolk H, Bradbury, a EUROCAT Working Group (2007) Increasing Prevalence of Gastroschisis in Europe 1980-2002: A Phenomenon Restricted to Younger Mothers? Paediatr Perinat Epidemiol 21:363-369 [Abstract]

Loane M, Dolk H, Kelly A, Teljeur C, Greenlees R, Densem J, a EUROCAT Working Group (2011) Paper 4: EUROCAT statistical monitoring: identification of ten year trends of congenital anomalies in Europe. Birth Defects Res A 91:S31-S43. https://doi.org/10. 1002/bdra. 20778

López-Camelo JS, Orioli IM, Dutra MG, Nazer-Herrera J, Rivera N, Ojeda ME (2005) Reduction of birth prevalence rates of neural tube defects after folic acid fortification in Chile. Am J Med Genet A 135: $120-125$

Martin S, De la Cruz J, Lanzoni M, Nicholl C (2016) Transfer of the central database and coordinating activities of EUROCAT to the JRC. ISBN 978-92-79-63771-1 see also JRC science hub https:// ec.europa.eu/jec. last accessed 15th August 2017
Mathews TJ, National Center for Health Statistics (2007) Trends in spina bifida and anencephalus in the United States, 1991-2005. National Center for Health Statistics, Hyattsville https://www.cdc.gov/nchs/ data/hestat/spine_anen/spine_anen.htm -accessed 24 ${ }^{\text {th }}$ August 2017

Morris JK, Rankin J, Garne E, Loane M, Greenlees R, Addor MC, Arriola L, Barisic I, Bergman JE, Csaky-Szunyogh M, Dias C (2016) Prevalence of microcephaly in Europe: population based study. bmj 354:i4721

Neville AJ, de Walle HEK (2010) Prevention of neural tube defects by periconceptional folic acid supplementation in Europe. Gynaecol Forum 15(4):16-20

Pirastu R, Ancona C, Iavarone I, Mitis F, Zona A, Comba P (2010) SENTIERI Project. Mortality study of residents in Italian polluted sites: evaluation of the epidemiological evidence. Epidemiol Prev 34(5-6):1-96

Sayed AR, Bourne D, Pattinson R, Nixon J, Henderson B (2008) Decline in the prevalence of neural tube defects following folic acid fortification and its cost-benefit in South Africa. Birth Defects Research Part A: Clinical and Molecular Teratology 82(4):211-216

Teljeur C, Kelly A, Loane M, Densem J, Dolk H (2015) Using scan statistics for congenital anomalies surveillance: the EUROCAT methodology. Eur J Epidemiol 30(11):1165-1173 